\title{
MicroRNA-133b aggravates atherosclerosis by activating the Notch signaling pathway
}

\author{
BAIZHI HAN ${ }^{1}$, TAO LI ${ }^{2}$ and SHILIANG ZHENG ${ }^{1}$ \\ ${ }^{1}$ Department of General Medicine, Affiliated Hospital of Weifang Medical University, Weifang, Shandong 261031; \\ ${ }^{2}$ Department of the Third Encephalopathy, Weifang Hospital of Traditional Chinese Medicine, \\ Weifang, Shandong 261041, P.R. China
}

Received May 30, 2019; Accepted February 24, 2020

DOI: $10.3892 / \mathrm{mmr} .2020 .11222$

\begin{abstract}
The aim of the present study was to investigate the effect of miR-133b on atherosclerosis (AS). A mouse model of AS (AS group) was established, and serum levels of total cholesterol, triglyceride, high-density lipoprotein cholesterol and low-density lipoprotein (LDL) cholesterol were detected. The thoracic aorta tissues were subjected to hematoxylin and eosin staining for pathological examination. Mice were intravenously injected with microRNA (miR)-133b mimics (the miR-133b mimic + AS group) and miR-133b mimics negative control (the miR-133b NC + AS group). Normal mice were named the Sham group. Vascular reconstruction parameters, the Collagen/Vascular Area Ratio (CA/CVA) and serum inflammatory factors of mice in each group were detected. mRNA expression was measured by reverse transcription-quantitative PCR and protein expression was determined by western blot analysis. An in vitro model of AS was induced in vascular smooth muscle cells (VSMCs) using oxidized (ox)-LDL. CCK-8 and wound healing assays were used to detect cell proliferation and migration. Compared with the Sham group, mice of the AS group, the AS + miR-133b NC group and the AS + miR-133b mimic group had higher intima thickness (IT), tumor necrosis factor (TNF)- $\alpha$ and monocyte chemoattractant protein (MCP)-1 levels, as well as increased Notch1 and Jagged1 expression; and they had lower medial thickness (MT), CA/CVA ratio and Notch3 expression (all $\mathrm{P}<0.05)$. In addition, miR-133b mimic promoted the proliferation and migration, upregulated Notch1 and Jagged1, and downregulated Notch3 in ox-LDL-induced VSMCs. Taken together, miR-133b aggravates AS by activating the Notch signaling pathway, which could serve as a potential target for the treatment of AS.
\end{abstract}

Correspondence to: $\mathrm{Dr}$ Tao $\mathrm{Li}$, Department of the Third Encephalopathy, Weifang Hospital of Traditional Chinese Medicine, 666 Weizhou Road, Kuiwen, Weifang, Shandong 261041, P.R. China E-mail: litao1819@163.com

Key words: atherosclerosis, miR-133b, Notch signaling pathway, vascular reconstruction, inflammatory factors

\section{Introduction}

Atherosclerosis (AS) is a chronic inflammatory disease that often occurs in the cardiovascular system. Important causes of AS include vascular endothelial cell injury, smooth muscle cell proliferation, monocyte or macrophage absorption of lipids and inflammatory mediator release (1-4). It has also been confirmed that the formation of AS is closely related to excess cholesterol and cholesterol esters in foam cells. The major sources of foam cells include macrophages, endothelial cells and vascular smooth muscle cells (VSMCs) $(5,6)$. Among these sources, SMCs can migrate into the vascular intima to form foam cells, thereby phagocytizing lipids. A large number of accumulated foam cells can form lipid streaks and cholesterol crystals, which eventually developed into atherosclerotic plaques under the influence of various factors (7). MicroRNAs (miRNAs) are a class of endogenous, non-coding RNAs of approximately 22 nucleotides in length that participate in numerous biological processes in vivo by regulating the expression of eukaryotic genes and the activity of important signaling pathways (8-10). Accumulating data have indicated that miRNAs are widely involved in the regulation of AS. Brennan et al (11), reported that the let-7 miRNA family exerted a protective effect on diabetes-associated AS via the inhibition of VSMC inflammatory responses, which may provide a possible therapeutic target for diabetes-associated AS. Research by Qun et al (12), showed that reduced miRNA-27b expression promoted plaque stability in AS by regulating CCL20/CCR6 axis activity by targeting $\mathrm{N}(\alpha)$-acetyltransferase 15 , NatA auxiliary subunit. de Ronde et al (13), also demonstrated that individuals who smoked had higher miR-124-3p expression than non-smokers, and this elevated miR-124-3p expression was associated with a higher risk of advanced AS and subclinical AS. In their paper, miR-124-3p was also shown to alter the phenotype of monocytes, thereby increasing the risk of AS in smokers.

miR-133b is a specific miRNA that plays an important role in neuron and embryonic heart development, adipocyte differentiation and tumorigenesis (14-17). Previous studies have confirmed that miR-133b is involved in the pathogenesis of a number of diseases, including various cancers (18), Parkinson's disease (19), chronic Chagas disease (20), atrial dilatation (21), cerebral ischemia (22) and AS (23). It has also been demonstrated that miR-133b acts as a tumor 
suppressor by targeting matrix metallopeptidase 9 (24), fascin actin-bundling protein 1 (25), peroxisome proliferator activated receptor $\gamma$ (26), homeobox A9 (27) and epidermal growth factor receptor (28). An miRNA profiling showed that miR-133b-3p is upregulated in diabetic AS in rats (29). In addition, Zheng et al (23) demonstrated that the downregulation of miR-133b inhibits the immune responses of macrophages, and attenuates the vulnerable plaque formation and vascular remodeling in AS mice via the mastermind-like transcriptional coactivator 1-mediated Notch-signaling pathway. However, the specific regulatory role of miR-133b in AS and its underlying mechanisms are not known.

The Notch pathway is involved in many physiological processes, such as embryo development, tumorigenesis, immunological function, and cardiac and vascular development $(30,31)$. Importantly, Notch signaling is involved in the occurrence, progression and prognosis of AS (32). Liu et al (33), reported that the Notch pathway is activated in AS plaques, resulting in endothelial inflammation and senescence. Davis-Knowlton et al (34), showed that the Notch signaling pathway is activated in the progression of AS, and plays a receptor-specific regulatory role in smooth muscle cells. However, it remains unclear whether the regulatory effect of miR-133b in AS is related to the Notch signaling pathway.

In the present study, the specific regulatory role of miR-133b in AS and its related-mechanism involving the Notch signaling pathway were analyzed. These results may provide a new experimental basis for the treatment of AS.

\section{Materials and methods}

Establishment of mouse AS model. A total of 60 healthy male apolipoprotein E-/- mice (6 weeks old, weighing 18-22 g) were purchased from the College of Pharmaceutical Sciences, Peking University. Among them, 20 mice (the Sham group) were randomly selected and fed with a normal diet, while the remaining 40 mice (the AS group) were fed with a high-fat $\operatorname{diet}(21 \%$ fat and $0.5 \%$ cholesterol). Mice were maintained in a controlled environment, at $23-25^{\circ} \mathrm{C}$ and $50-60 \%$ humidity, with a 12-h light/dark cycle and free access to food and water. All the mouse feeds were provided by Keao Xieli Experimental Animal Feed Co., Ltd.

Measurement of serum total cholesterol (TC), triglyceride (TG), high density lipoprotein cholesterol $(H D L-C)$ and low density lipoprotein cholesterol $(L D L-C)$. After 13 weeks of feeding, all mice were starved for $12 \mathrm{~h}$ and anesthetized by intraperitoneal injection of diazepam $(5 \mathrm{mg} / \mathrm{kg})$ and ketamine $(50 \mathrm{mg} / \mathrm{kg}$ ) to collect cardiac venous blood. The collected blood was centrifuged at $1,800 \mathrm{x}$ g for $15 \mathrm{~min}$ at $4^{\circ} \mathrm{C}$ to obtain serum. TC, TG, HDL-C and LDL-C levels in serum were detected using OLYMPUS AU2700 automatic blood lipid analyzer (Olympus Corporation).

Haematoxylin and eosin $(H \& E)$ staining. At the 13th week, mice in the Sham group $(\mathrm{n}=10)$ and the AS group $(\mathrm{n}=10)$ were randomly selected and anesthetized by intraperitoneal injection of diazepam $(5 \mathrm{mg} / \mathrm{kg})$ and ketamine $(50 \mathrm{mg} / \mathrm{kg})$, and then sacrificed by cervical dislocation. After immersion into $75 \%$ ethanol for $5 \mathrm{~min}$, the mice were subjected to thoracotomy to obtain the thoracic aorta tissues. Pre-cooled PBS was used to remove residual blood from the thoracic aorta. Excess extra vascular tissues were removed. Subsequently, the thoracic aorta was fixed in $4 \%$ paraformaldehyde for $24 \mathrm{~h}$ at $25^{\circ} \mathrm{C}$, embedded in paraffin and sliced into $4-\mu \mathrm{m}$ sections for $\mathrm{H} \& \mathrm{E}$ staining. Briefly, these sections were de-waxed three times with toluene for 5 min each time, then dehydrated with gradient alcohol and washed with pure water. The sections were stained with hematoxylin for $2 \mathrm{~min}$ and with eosin for $2 \mathrm{~min}$, both at $25^{\circ} \mathrm{C}$. After being dehydrated by gradient alcohol and xylene, all sections were sealed with neutral resin and observed under a light microscope (magnification, x200).

Transfection in vivo. The miRNA delivery method used in this study was performed in accordance with previous protocols (35-37). This method may be used in the evaluation of the regulatory effects of miR-133b overexpression on AS. A total of 20 mice randomly selected from the AS group were divided into two groups, which were named the miR-133b mimic + AS group and the miR-133b negative control (NC) + AS group. According to the instructions of EntransterTM-in vivo reagent (Engreen Biosystem Co., Ltd.), the mice in both groups were intravenously injected with $10 \mathrm{mg} / \mathrm{kg}$ miR-133b mimic (forward, 5'-UUUGGUCCCCUUCAACCAGCUA-3' and reverse, 5'-GCUGGUUGAAGGGGACCAAAUU-3') and miR-133b NC (forward, 5'- UUCUCCGAACGUGUCACGUTT-3' and reverse, 5'- ACGUGACACGUUCGGAGAATT-3') via the tail vein, respectively. The injection was administered every week and lasted for 4 weeks. Before injection, the tail vein was wiped with $75 \%$ alcohol so it was fully congested and expanded. miR-133b mimic and miR-133b NC were synthesized by Shanghai Jima Pharmaceutical Technology Co., Ltd. The subsequent experiments were performed following 4 weeks of transfection.

Detection of inflammatory factors. Thoracic aorta tissues were homogenated. The levels of tumor necrosis factor (TNF)- $\alpha$ (cat. no. KRC3011C) and monocyte chemoattractant protein (MCP)-1 (cat. no. BMS6005TEN) in the tissues were detected using ELISA kits (Thermo Fisher Scientific, Inc.), according to the manufacturers' protocols.

Vascular reconstruction parameters and Collagen/Vascular Area Ratio (CA/CVA) determination. The thoracic aorta tissues of mice in each group were obtained 3 days after transfection according to the acquisition method described above. Thoracic aorta tissues were fixed in $4 \%$ paraformaldehyde at $25^{\circ} \mathrm{C}$ for $24 \mathrm{~h}$. After being embedded in paraffin, these vascular tissues were cut into $4-\mu \mathrm{m}$ thick sections and stained with Masson staining for $10 \mathrm{~min}$ at $25^{\circ} \mathrm{C}$, then washed with $0.2 \%$ aqueous acetic acid for $1 \mathrm{~min}$ and soaked with $1 \%$ phosphotungstic acid for 4 min (Sigma-Aldrich; Merck $\mathrm{KGaA}$ ). Before staining with a bright green dye solution (Sigma-Aldrich; Merck KGaA) for $30 \mathrm{sec}$ at $25^{\circ} \mathrm{C}$, all the sections were washed again with $0.2 \%$ aqueous acetic acid for $1 \mathrm{~min}$. Gradient alcohol and xylene were then used to dehydrate all sections. Lastly, these sections were sealed with neutral gum and observed under a light microscope (magnification, x200). Intima thickness (IT), medial thickness (MT) and collagen area (CA) were detected using Image-Pro Plus 
5.1 Pathology Image Analysis System (Media Cybernetics, Inc.). The ratio of CA/CVA (\%) was calculated using the following equation: (CA/CAV) x 100.

Reverse transcription-quantitative $(R T-q) P C R$. Total RNA in thoracic aorta tissues was collected using TRIzol ${ }^{\circledR}$ reagent (Thermo Fisher Scientific, Inc.), according to the manufacturer's protocol. A total of $300 \mathrm{ng}$ RNA was synthesized into cDNA templates with the PrimeScript RT reagent kit (Takara Bio, Inc.) at $42^{\circ} \mathrm{C}$ for $45 \mathrm{~min}$. These cDNA templates were amplified through RT-qPCR with a SYBR ${ }^{\circledR}$ Green kit (Takara Bio, Inc.) on an ABI PRISM 7500 Sequence Detection System (Applied Biosystems; Thermo Fisher Scientific, Inc.). The following thermocycling conditions were used: $95^{\circ} \mathrm{C}$ for $3 \mathrm{~min}$; and 40 cycles of $95^{\circ} \mathrm{C}$ for $15 \mathrm{sec}$ and $60^{\circ} \mathrm{C}$ for $30 \mathrm{sec}$. U6 was set as the internal control for miRNAs, and GAPDH served as the internal control for other genes. Primer sequences involved in this study were as follows: miR-133b forward, 5'-TTTGGTCCCCTTCAACCAGCTA-3' and reverse, 5'-GTGCAGGGTCCGAGGT-3'; Notch1 forward, 5'-TCGCCGCAAGAGGCTTGAGATGCT-3' and reverse, 5'-TCCGCTGCAGCACAGGCTTCA-3'; Notch3 forward, 5'-TCGCAACTGCCGAAGCGACA-3' and reverse, 5'-GCGCAGGGCAGTATGGGGTTTT-3'; Jaggedl forward, 5'-CAGCGCACGCCGACAAAAC-3' and reverse, 5'-TATGGCGGCACGCACTGTCT-3'; U6 forward, 5'-CTCGCTTCGGCAGCACATATACT-3' and reverse, 5'-ACGCTTCACGAATTTGCGTGTC-3'; GAPDH forward, 5'-CCACCCATGGCAAATTCCATGGCA-3' and reverse, 5'-TCTAGACCGCAGGTCAGGTCCACC-3'. The relative expression of genes was determined by the $2-{ }^{\Delta \Delta \mathrm{Cq}}$ method (38).

Western blot analysis. The thoracic aorta tissues were ground in liquid nitrogen and lysed with RIPA lysis buffer (cat. no. P0013C; Beyotime Institute of Biotechnology). Total protein was quantified by the BCA method and transferred to a PVDF membrane after separation by $10 \%$ SDS-PAGE (30 $\mu \mathrm{g} /$ lane). Subsequently, the membrane was blocked with $5 \%$ skimmed milk at $4^{\circ} \mathrm{C}$ for $1 \mathrm{~h}$. Primary antibodies used in this research were rabbit anti-Notch1 (cat. no. ab194123; Abcam; 1:5,000), anti-Notch3 (cat. no. ab23426; Abcam; 1:5,000) and anti-Jagged1 antibodies (cat. no. ab7771; Abcam; 1:5,000). The PVDF membrane was incubated with primary antibodies at $4^{\circ} \mathrm{C}$ for $12 \mathrm{~h}$. Then, the membrane was washed with TBS with $0.1 \%$ Tween 20 (TBST) for $15 \mathrm{~min}$ and incubated with a horseradish peroxidase-labeled goat anti-rabbit IgG secondary antibody (cat. no. ab6721; Abcam; 1:5,000) for $2 \mathrm{~h}$ at $25^{\circ} \mathrm{C}$. The membrane was then washed with TBST for $15 \mathrm{~min}$. Enhanced Chemiluminescence system (GE Healthcare) was used to visualize proteins. Lab Works 4.5 software (UVP, LLC) was selected to analyze the integrated optical density. $\beta$-actin was used as an internal reference.

Cell culture and treatment. Mouse VSMCs (CRL-2797) were purchased from the American Type Culture Collection. Cells were cultured with DMEM (Gibco; Thermo Fisher Scientific, Inc.) containing $10 \% \mathrm{FBS}$ and $1 \%$ penicillin/streptomycin. VSMCs were treated with different concentrations of oxidized low-density lipoprotein (ox-LDL; 0, 25, 50 and $75 \mu \mathrm{g} / \mathrm{ml}$ ) for $24 \mathrm{~h}$, or with $50 \mu \mathrm{g} / \mathrm{ml}$ ox-LDL for different times $(0,12,24$ and $48 \mathrm{~h}$ ), both at $25^{\circ} \mathrm{C}$. VSMCs without treatment were the control. Subsequently, VSMCs were transfected with $100 \mathrm{nM}$ miR-133b mimic (Control + mimic) and $100 \mathrm{nM}$ miR-133b $\mathrm{NC}$ (Control + NC) for $24 \mathrm{~h}$. ox-LDL induced-VSMCs $(24 \mathrm{~h}$, $50 \mu \mathrm{g} / \mathrm{ml})$ were transfected with $100 \mathrm{nM}$ miR-133b mimic (ox-LDL + mimic) and $100 \mathrm{nM}$ miR-133b NC (ox-LDL + NC) for $24 \mathrm{~h}$. Cell transfection was performed using Lipofectamine ${ }^{\circledR}$ 2000 reagent (Invitrogen; Thermo Fisher Scientific, Inc.), following the manufacturer's protocols. The subsequent experiments were performed at $24 \mathrm{~h}$ post-transfection.

CCK-8 assay. Cell proliferation was detected by a CCK-8 Assay Kit (Beyotime Institute of Biotechnology), according to the manufacturer's protocol. Simply, cells were seeded into a 96-well plate and $50 \mu \mathrm{l}$ CCK-8 solution was added into each well. After $3 \mathrm{~h}$ of incubation, the optical density (OD) at $450 \mathrm{~nm}$ was detected by a microplate reader (Molecular Devices).

Wound healing assay. Cell migration was detected by the wound healing test. Briefly, cells were seeded into a 6-well plate and cultured until $90 \%$ confluence, and then cultured in FBS-free DMEM overnight. A sterile pipette tip was used to draw a vertical line on the cell surface. Cells were subsequently cultured in FBS-free DMEM for $24 \mathrm{~h}$, with the scratch width measured at 0 and $24 \mathrm{~h}$. Cells were observed under a light microscope (magnification, x100). The migration rate (\%) was calculated as: $(1$ - scratch width at $24 \mathrm{~h} / \mathrm{scratch}$ width at $0 \mathrm{~h}) \mathrm{x} 100$.

Statistical analysis. Experimental data were expressed as mean \pm SD. SPSS 19.0 (IBM Corp.) was used for data processing. Two-tailed Student's t-test was used to compare the differences between two groups and one-way ANOVA was selected to compare the differences among multiple groups, followed by a Tukey's post hoc test. $\mathrm{P}<0.05$ was considered to be statistically significant and all experiments were performed three times.

\section{Results}

Successful establishment of AS mouse model. Serum TC, TG and LDL-C levels of mice in the AS group were significantly higher than those in the Sham group $(\mathrm{P}<0.01)$ at the 13 th week. By contrast, the serum level of HDL-C in the AS group was found to be significantly lower than the Sham group $(\mathrm{P}<0.01$; Fig. 1A-D). The thoracic aorta vessels of mice in each group were stained with H\&E stain (Fig. 1E). In the Sham group, thoracic aorta vessels had smooth intima, intact endothelial cells and uniform blood vessel thickness. Smooth muscle cell proliferation and inflammatory cell infiltration were not observed. However, typical AS plaques protruding to the vascular lumen was found in the thoracic aorta vessels of the AS group. The subendothelial space was widened, and migration of smooth muscle cells and foam cells were observed. Mesangial smooth muscle cells showed obvious hyperplasia. There were a large number of newly added smooth muscle cells near the outer membrane. Inflammatory cell infiltration was easily detected. This showed the successful construction of mice AS models. 

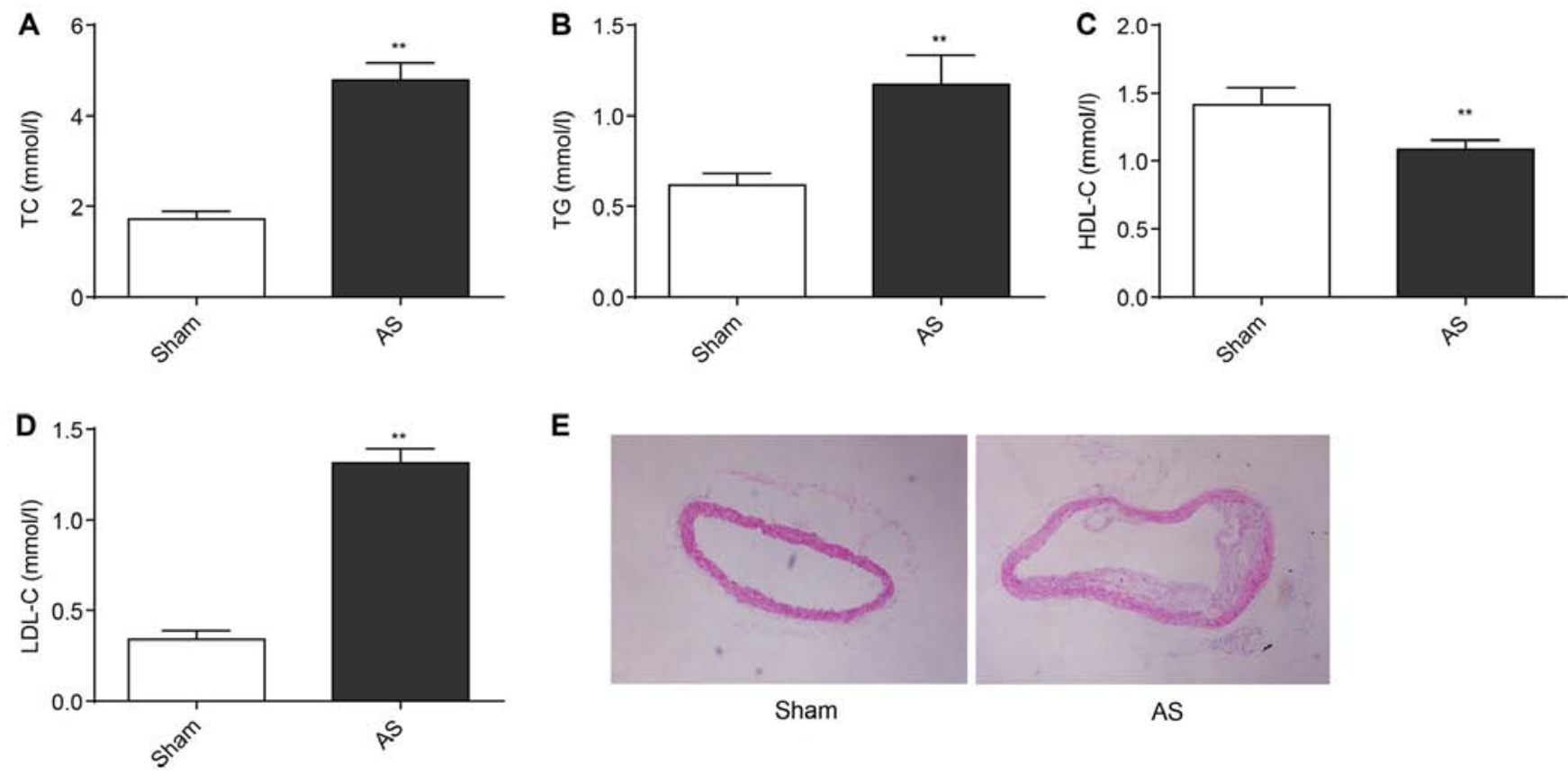

E

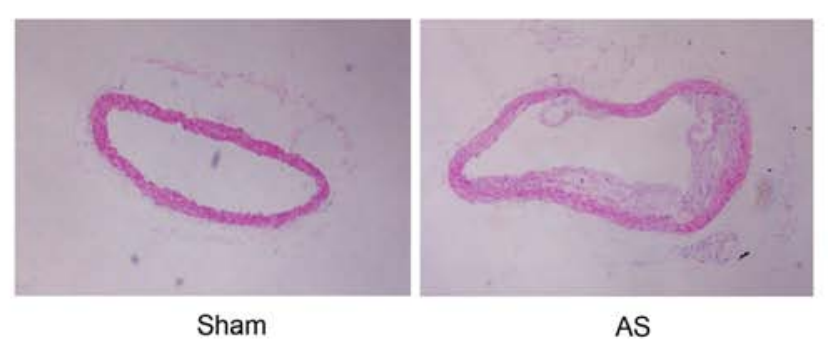

Figure 1. AS mouse models were successfully constructed. Levels of (A) TC, (B) TG, (C) HDL-C and (D) LDL-C in serum from mice. (E) Hematoxylin and eosin staining of thoracic aorta vessels. ${ }^{* *} \mathrm{P}<0.01$ vs. Sham group. Magnification, $\mathrm{x} 50$. AS, atherosclerosis; TC, total cholesterol; TG, triglyceride; HDL-C, high density lipoprotein-cholesterol; LDL-C, low density lipoprotein-cholesterol.

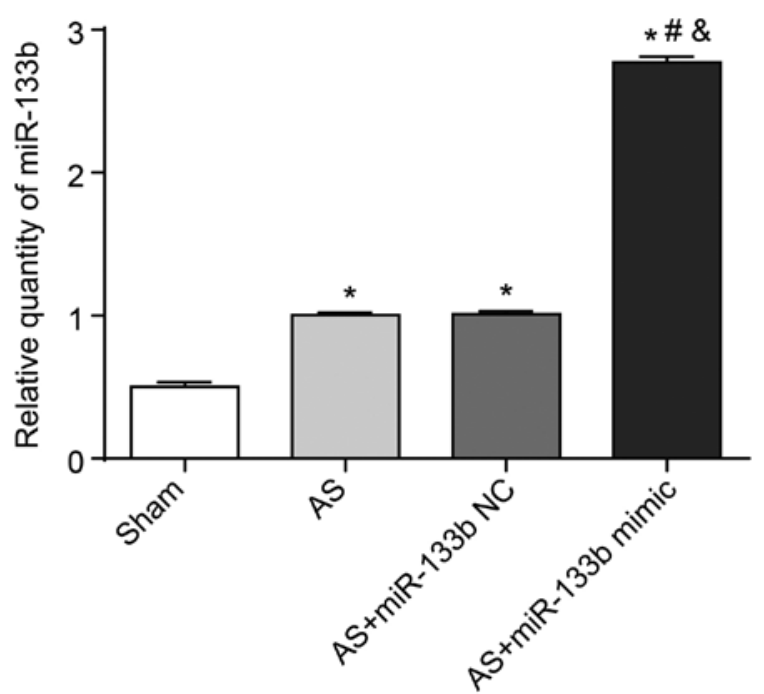

Figure 2. Mice were successfully transfected in vivo. Levels of miR-133b in each group were measured to confirm successful transfection. ${ }^{*} \mathrm{P}<0.05$ vs. Sham group; ${ }^{~} \mathrm{P}<0.05$ vs. AS group; ${ }^{\&} \mathrm{P}<0.05$ vs. AS + miR-133b NC group. AS, atheroscelorsis; NC, negative control; miR, microRNA.

Successful transfection in mice. After 3 days of transfection in vivo, the expression of miR-133b in the mouse thoracic aorta was determined by RT-qPCR. As shown in Fig. 2, the expression of relative miR-133b in the thoracic aorta of the AS group, the AS + miR-133b NC group and the AS + miR-133b mimic group were all significantly higher than that of the Sham group $(\mathrm{P}<0.05)$. In addition, the relative expression of miR-133b in thoracic aorta of the AS + miR-133b mimic group was significantly higher than that of the AS group and the AS + miR-133b NC group $(\mathrm{P}<0.05)$. No significant difference in relative miR-133b expression was found in the thoracic aorta between the AS group and the AS + miR-133b NC group. Therefore, miR-133b expression in the thoracic aorta was successfully upregulated by transfection in vivo.

Overexpression of $m i R-133 b$ aggravates $A S$. Compared with the Sham group, IT increased in the thoracic aorta of the AS group, the AS + miR-133b NC group and the AS + miR-133b mimic group, whereas MT and the ratio of CA/CVA decreased in the thoracic aorta of these groups $(\mathrm{P}<0.05)$. Furthermore, these same results were also found in the thoracic aorta of the AS + miR-133b mimic group when compared to the AS group and the $\mathrm{AS}+$ miR-133b NC group $(\mathrm{P}<0.05)$. There was no obvious difference in IT, MT and the ratio of CA/CVA between the AS group and the AS + miR-133b NC group (Fig. 3A-C). All these results indicated that overexpression of miR-133b aggravated AS.

Overexpression of miR-133b increases inflammatory factor levels. TNF- $\alpha$ and MCP-1 are two important inflammatory factors (39). In the present study levels of TNF- $\alpha$ and MCP-1 were significantly upregulated in thoracic aorta tissues in mice of the AS group, the AS + miR-133b NC group and the $\mathrm{AS}+\mathrm{miR}-133 \mathrm{~b}$ mimic group when compared with the Sham group $(\mathrm{P}<0.05)$. This was also detected in thoracic aorta tissues of the AS + miR-133b mimic group when compared with the AS group and the AS + miR-133b NC group $(\mathrm{P}<0.05$; Fig. 4A and B). Overexpression of miR-133b increased the inflammatory factor levels of AS mice, thereby worsening AS.

Overexpression of $m i R-133 b$ aggravates $A S$ by activating the Notch signaling pathway. The Notch signaling pathway plays an important regulatory role in a variety of diseases (40). Therefore, the effects of miR-133b on the Notch signaling pathway in this paper were studied. It was found that the rela- 

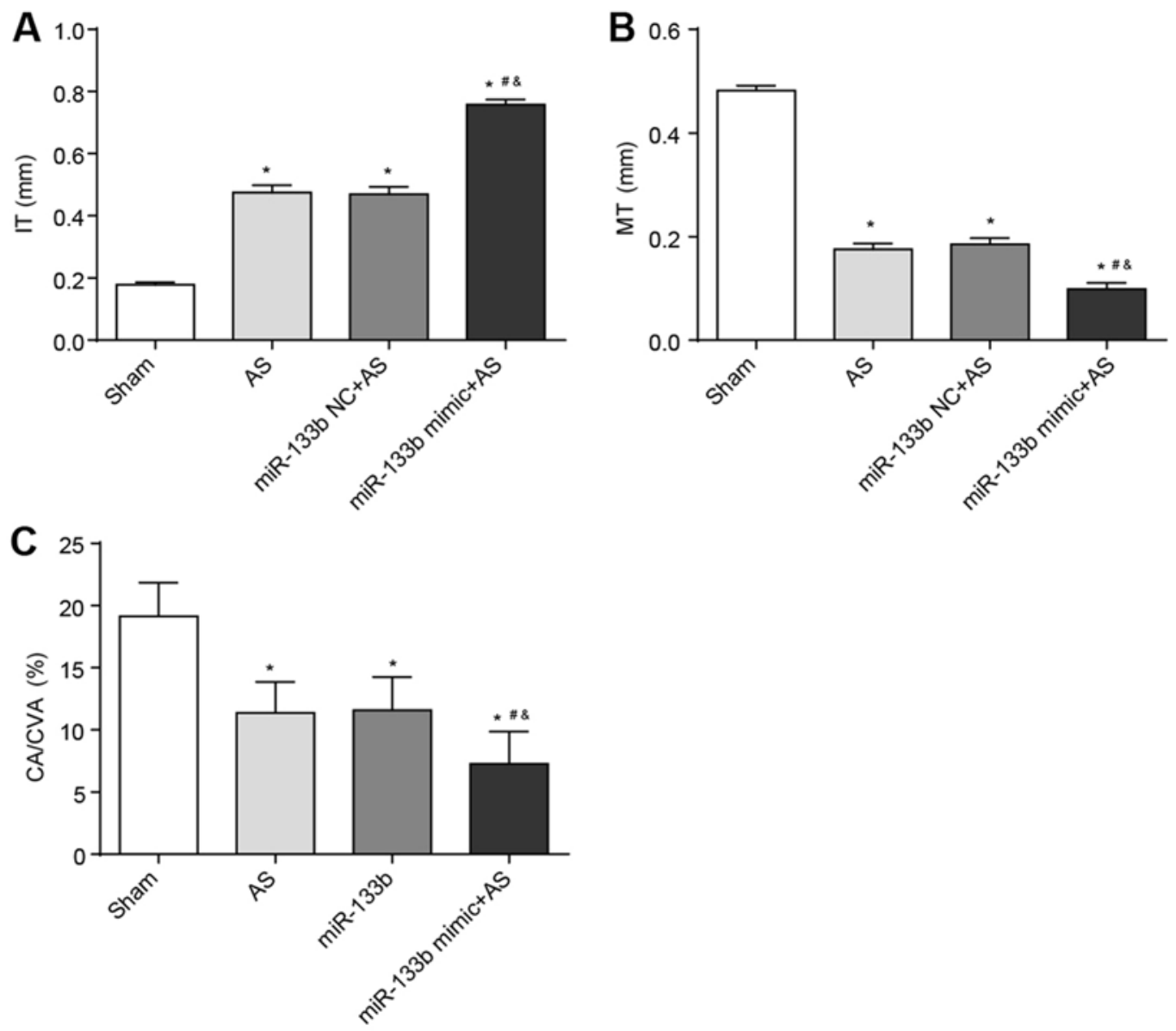

Figure 3. Overexpression of miR-133b aggravated AS. Measurement of (A) IT, (B) MT and (C) CA/CVA ratio of the thoracic aorta. "P<0.05 vs. Sham group; ${ }^{\#} \mathrm{P}<0.05$ vs. AS group; ${ }^{\&} \mathrm{P}<0.05$ vs. AS + miR-133b NC group. IT, intima thickness; MT, medial thickness; CA/CVA, collagen/vascular area ratio; miR, microRNA; AS, atherosclerosis; NC, negative control.
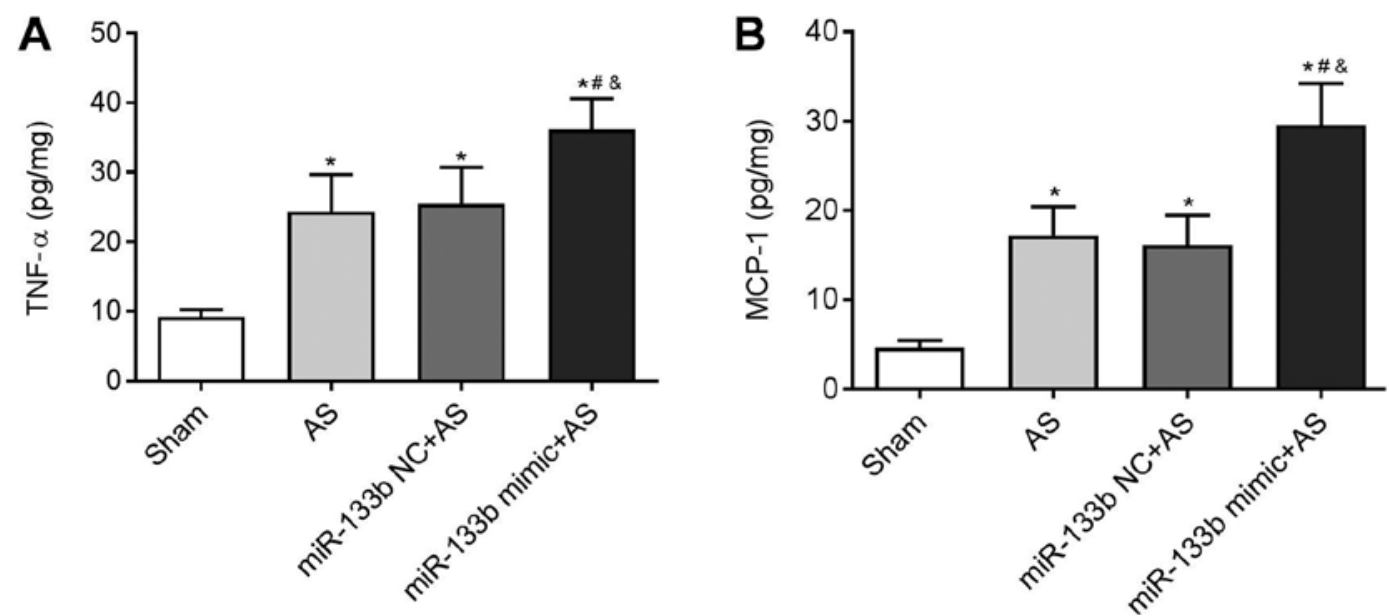

Figure 4. Overexpression of miR-133b increased the levels of inflammatory factors in thoracic aorta tissues of AS mice. (A) TNF- $\alpha$ and (B) MCP-1 levels detected by ELISA. ${ }^{*} \mathrm{P}<0.05$ vs. Sham group; ${ }^{\sharp} \mathrm{P}<0.05$ vs. AS group; ${ }^{\&} \mathrm{P}<0.05$ vs. AS + miR-133b NC group. miR, microRNA; AS, atherosclerosis; TNF- $\alpha$, tumor necrosis factor $\alpha$; MCP-1, monocyte chemoattractant protein $1 ; \mathrm{NC}$, negative control.

tive expression of Notch1 and Jagged1 in the AS + miR-133b group was significantly higher than that in the AS group and AS + miR-133b NC group when compared with the Sham group $(\mathrm{P}<0.05)$. In addition, the relative expression of the Notch1 and Jagged1 in the thoracic aorta in the AS + miR-133b mimic group was significantly upregulated compared to the AS group and the AS + miR-133b NC group $(\mathrm{P}<0.05)$. However, the Notch3 relative expression level, was much lower in the $\mathrm{AS}+$ miR-133b mimic group than that in the AS group and the $\mathrm{AS}+$ miR-133b NC group $(\mathrm{P}<0.05$; Fig. 5A-D). These results 

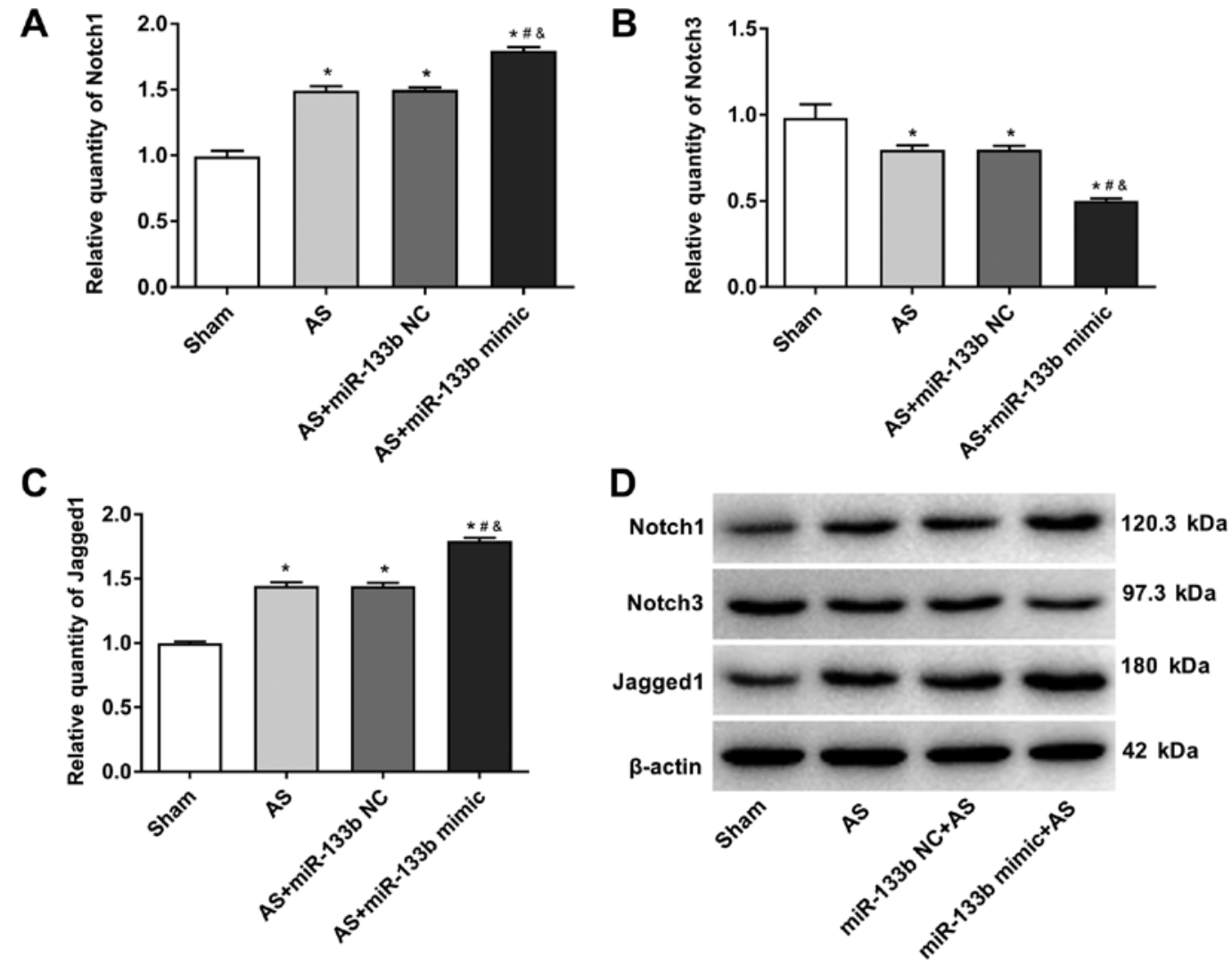

Figure 5. Overexpression of miR-133b aggravated AS by activating the Notch signaling pathway. Reverse transcription-quantitative PCR determined mRNA expression of (A) Notch1, (B) Notch3 and (C) Jagged1 in the thoracic aorta. (D) Western blot image showing the protein expression of Notch1, Notch3 and Jagged 1 in the thoracic aorta. " $\mathrm{P}<0.05$ vs. Sham group; ${ }^{\text {} P}<0.05$ vs. AS group; ${ }^{\&} \mathrm{P}<0.05$ vs. AS + miR-133b NC group. miR, microRNA; AS, atherosclerosis; $\mathrm{NC}$, negative control.

suggested that overexpression of miR-133b may aggravate AS by activating the Notch signaling pathway.

Overexpression of $\mathrm{miR}-133 \mathrm{~b}$ promotes cell proliferation and migration, and activates Notch signaling pathway in ox-LDL-induced VSMCs. An in vitro AS model was induced in VSMCs by the treatment of ox-LDL. As shown in Fig. 6A and B, ox-LDL treatment significantly increased the expression of miR-133b in a dose- and time-dependent manner $(\mathrm{P}<0.05)$. The $24 \mathrm{~h}$ ox-LDL treatment at a concentration of $50 \mu \mathrm{g} / \mathrm{ml}$ was used for subsequent experiments. The CCK-8 and wound healing assay showed that the $\mathrm{OD}_{450}$ value and the migration rate of ox-LDL-induced VSMCs were significantly higher than those in the control group $(\mathrm{P}<0.01$; Fig. $6 \mathrm{D}$ and $\mathrm{E})$. Western blotting showed that the expression of Notch1 and Jagged1 significantly increased, and the expression of Notch3 significantly decreased in ox-LDL-induced VSMCs $(\mathrm{P}<0.01$; Fig. $6 \mathrm{~F})$. To identify the regulatory role of miR-133b in $\mathrm{AS}, \mathrm{miR}-133 \mathrm{~b}$ was overexpressed in VSMCs by the transfection of miR-133b mimics. RT-qPCR showed that the expression of miR-133b was significantly increased in miR-133b mimics-transfected VSMCs and ox-LDL-induced VSMCs ( $\mathrm{P}<0.01$; Fig. 6C). The transfection of miR-133b mimics significantly increased the $\mathrm{OD}_{450}$ value and migration rate, upregulated Notch1 and Jagged1, and downregulated Notch3 in ox-LDL-induced VSMCs ( $\mathrm{P}<0.01$; Fig. 6D-F). These results indicated that the miR-133b overexpression promoted the proliferation and migration of ox-LDL-induced VSMCs, and activated the Notch signaling pathway.

\section{Discussion}

AS is the core pathological cause of acute cerebral infarction, which can lead to carotid stenosis and reduce blood supply to the brain (41). When stenosis is continuously increased or the important cerebral artery is blocked due to detached plaques, acute cerebral blood supply blockage and ischemic hypoxia injury of the nervous system is more likely to occur, thereby posing a great threat to the health and life of patients $(42,43)$. Early diagnosis and effective treatment are important strategies to improve the prognosis of patients with AS. miR-133b has been reported to be involved in the development of a variety of tumors, such as gastric cancer, ovarian cancer and non-small cell lung cancer $(15,24,26,44,45)$. However, the regulatory effect of miR-133b on AS development and related action mechanism remains unclear. In the present study, mice AS models were successfully constructed, and miR-133b was shown to aggravate AS by activating the Notch signaling pathway.

AS is a chronic inflammation and immune response to the injury and stimulation of the arterial wall (46). In the early stages of AS formation, monocytes that accumulate at the injury site pass through the vascular endothelium, thereby activating and differentiating into macrophages (47-50). The foam cells formed by the lipidation of macrophages are the initiating factors of AS (51). VSMCs, which are abundant in the vascular media, migrate into the intima of vascular and phagocytose the lipid to form muscle-derived foam cells, 

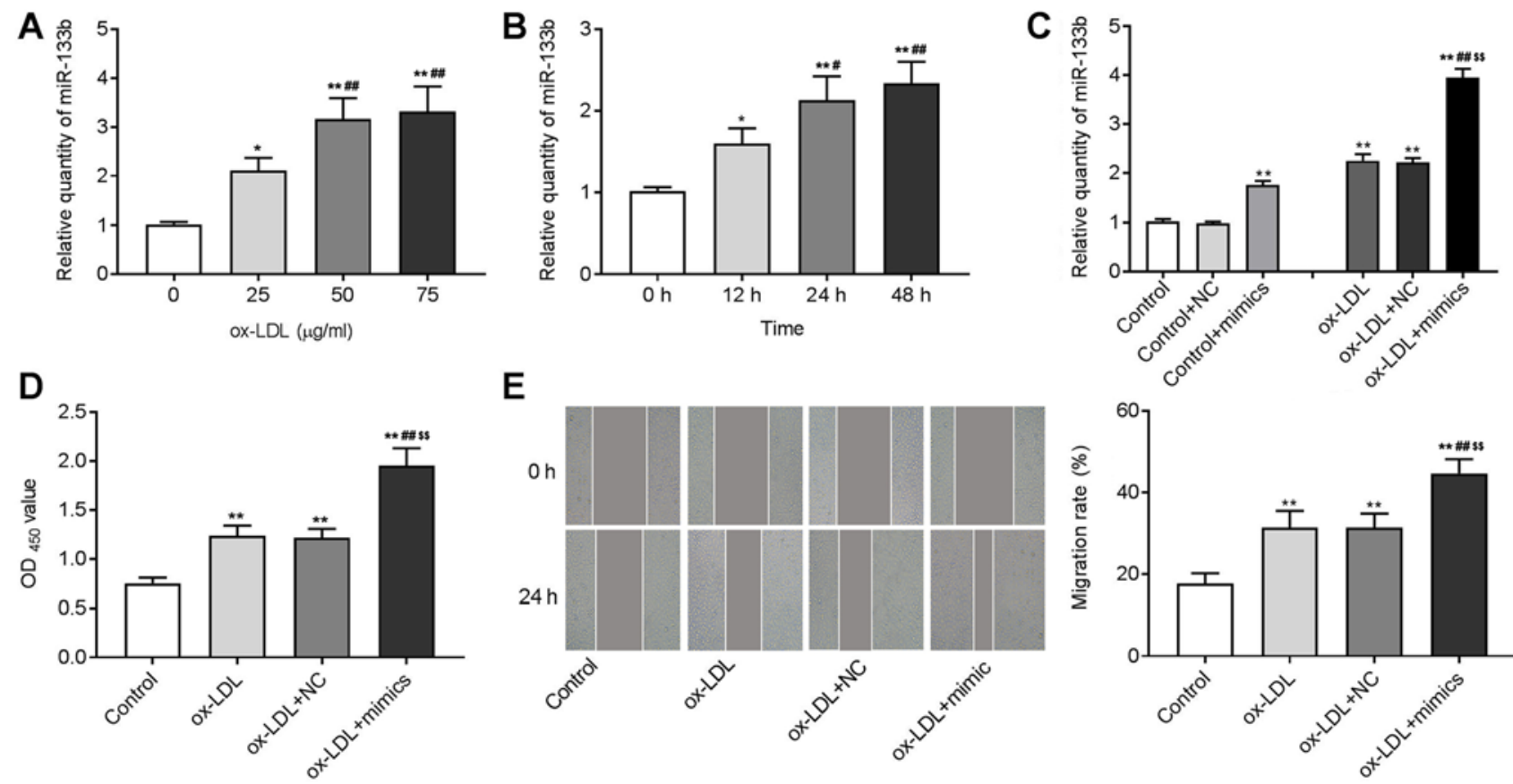

E
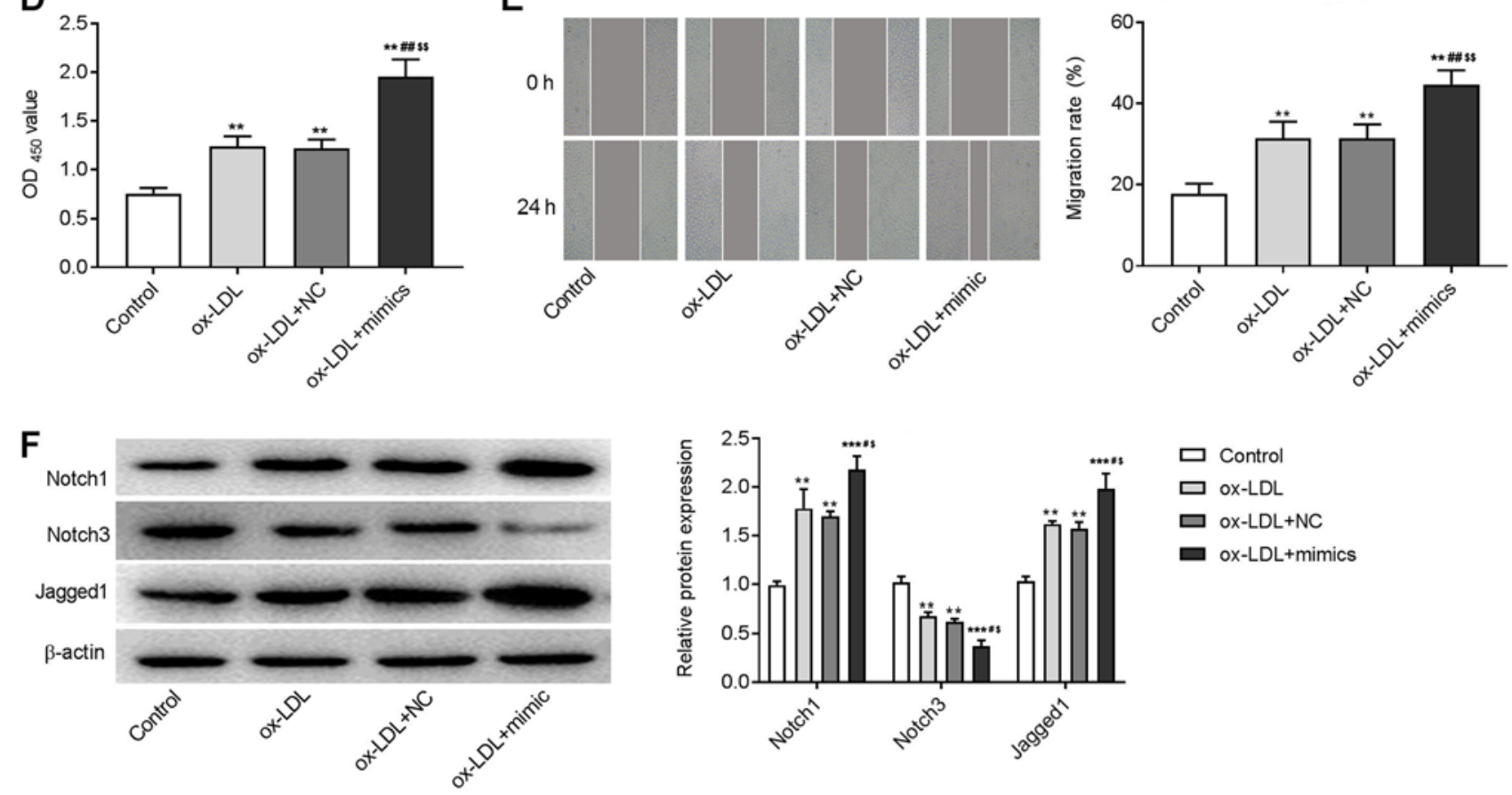

Figure 6. Overexpression of miR-133b promoted cell proliferation and migration, and activated Notch signaling pathway in ox-LDL-induced VSMCs Expression of miR-133b in VSMCs treated with ox-LDL for (A) different concentrations and (B) times was detected by RT-qPCR; ${ }^{\mathrm{P}}<0.05$, ${ }^{* * *} \mathrm{P}<0.01 \mathrm{vs} .0 \mu \mathrm{g} / \mathrm{ml}$ or $0 \mathrm{~h} ;{ }^{\#} \mathrm{P}<0.05,{ }^{\# \#} \mathrm{P}<0.01$ vs. $25 \mu \mathrm{g} / \mathrm{ml}$ or $12 \mathrm{~h}$. (C) Expression of miR-133b in VSMCs/ox-LDL-induced VSMCs transfected with miR-133b mimic/NC was detected by RT-qPCR. (D) Proliferation of VSMCs was detected by CCK-8 assay (OD 450). (E) Migration of VSMCs was detected by wound healing assay (magnification, $\mathrm{x} 400$ ). (F) Protein expression of Notch1, Notch3 and Jagged1 was detected by western blotting. ${ }^{* *} \mathrm{P}<0.01,{ }^{*{ }^{* * *}} \mathrm{P}<0.001$ vs. Control group; ${ }^{"} \mathrm{P}<0.05$, ${ }^{\# \#} \mathrm{P}<0.01$ vs. ox-LDL group; ${ }^{\$} \mathrm{P}<0.05,{ }^{\$ \$} \mathrm{P}<0.01$ vs. ox-LDL + NC group. miR, microRNA; ox-LDL, oxidized low density lipoprotein; VSMCs, vascular smooth muscle cells; RT-qPCR, reverse transcription-quantitative PCR; NC, negative control; OD, optical density.

and eventually form fibrous plaques $(52,53)$. In the present study, it was observed that overexpression of miR-133b induced increased IT and decreased MT, which may be caused by the migration of a large number of VSMCs into the intima. In addition, the ratio of CA/CVA decreased as a result of miR-133b overexpression. This is important because collagen is the main component of vascular remodeling (54), it has been shown that if collagen is reduced the original vascular lumen cannot be maintained $(55,56)$. Thus leading to the loss of the compensatory mechanism where the vascular wall can expand, therefore leading to luminal stenosis and aggravated AS (57-59). Inflammatory responses are also important factors that trigger and exacerbate AS (60). TNF- $\alpha$ and MCP-1 are two important pro-inflammatory factors (61). TNF- $\alpha$, which is mainly secreted by activated monocytes/macrophages, is a cytokine with multiple functions and an important mediator of inflammatory responses (62). Tay et al (63), found that B2 lymphocytes promote cell death and inflammation by increasing TNF- $\alpha$ production, which is a key mechanism for promoting atherogenesis. Voloshyna et al (64), also reported that TNF- $\alpha$ could result in an atherogenic state by decreasing the expression of ATP binding cassette transporters A1 as a pro-inflammatory atherogenic cytokine. Gandhirajan et al (65), discovered that TNF- $\alpha$ could induce proliferation and migration of human VSMCs. In the present study it was found that overexpression of miR-133b increased TNF- $\alpha$ level, which might further aggravate AS by promoting the proliferation and migration of VSMCs. MCP-1 has been considered as an important factor in the formation of AS, and some scholars have proposed to detect the degree of AS and predict the risk of long-term cerebral infarction by detecting the level of MCP-1 (66). MCP-1 is capable of chemotaxis of monocyte macrophages. It can induce the production of various pro-inflammatory factors, promote the expression of adhesion molecules and accelerate the formation of foam cells (67). In the present research, elevated MCP-1 levels induced by overexpression of miR-133b exacerbated 
the development of AS. Notch signaling pathway has been shown to have an important role in regulating the survival, migration and phenotype of VSMCs (68). Beaten and Lilly (69) demonstrated that the Notch signaling pathway was involved in the vascular development by influencing angiogenesis, vessel patterning, arterial/venous specification and VSMC differentiation.Sweeney et al (70), demonstrated that the apoptosis of rat VSMCs significantly increased after the Notch signaling pathway was inhibited using RPMS-1 or brefeldin A. Previously, researchers revealed that in AS, the Notch signaling pathway was activated in aged human endothelial cells, and several important inflammatory factors were significantly upregulated in endothelial cells when the Notch signaling pathway was activated (71). Thus, the Notch signaling pathway was proposed to be a potential target for the treatment of AS. In the present study it was discovered that the Notch signaling pathway was activated by the upregulation of miR-133b, which further led worsened AS. These findings indicated that miR-133b is involved in the development of AS, which is consistent with previous studies $(23,29)$. However, the specific role of miR-133b in AS is contrary to that in tumors, where it has been shown to have a tumor inhibiting effect (24-28). This conflict may attribute to the different functions of miR-133b in different diseases.

This study exhibited some limitations. First, the upstream and downstream genes that regulate miR-133b were not investigated in relation to AS progression, so they are still unclear. Second, the regulatory role of the Notch pathway in AS was not evaluated. Third, the regulatory relationship between miR-133b and other important signaling pathways, such as PI3K and MAPK signaling were not evaluated in the AS model. Fourth, the effects of miR-133b downregulation in AS was not analyzed. Lastly, the effect of statin therapy on miR-133b expression in AS was not analyzed. Further studies exploring these mechanisms are needed.

To conclude, miR-133b was upregulated in the mouse model of AS and ox-LDL-induced VSMCs. The overexpression of miR-133b promoted vascular remodeling and inflammation in AS mice, and the proliferation and migration of ox-LDL-induced VSMCs in vitro. The regulatory role of miR-133b in AS was closely associated with the activation of the Notch signaling pathway. It is hypothesized that miR-133b downregulation may inhibit vascular remodeling and inflammation, as well as the proliferation and migration of VSMCs by blocking the Notch signaling pathway. Thus, miR-133b may serve as a potential therapeutic target for the treatment of AS.

\section{Acknowledgements}

Not applicable.

\section{Funding}

No funding was received.

\section{Availability of data and materials}

The datasets used and/or analyzed during the current study are available from the corresponding author on reasonable request.

\section{Authors' contributions}

TL conceived and designed the study; $\mathrm{BH}$ and SZ acquired and analyzed the data; TL and BH drafted the manuscript; and TL revised the manuscript for critically important intellectual content. All authors read and approved the final manuscript.

\section{Ethics approval and consent to participate}

The current study was conducted after obtaining the approval of Weifang Hospital of Traditional Chinese Medicine's Ethical Committee. Animal experiments were approved by the Animal Experimental Ethics Committee of our hospital.

\section{Patient consent for publication}

Not applicable.

\section{Competing interests}

The authors declare that they have no competing interests.

\section{References}

1. Liu J, Jiang C, Ma X and Wang J: Notoginsenoside Fc attenuates high glucose-induced vascular endothelial cell injury via upregulation of PPAR- $\gamma$ in diabetic Sprague-Dawley rats. Vascul Pharmacol 109: 27-35, 2018.

2. Baumer Y, McCurdy S, Alcala M, Mehta N,Lee BH, Ginsberg MH and Boisvert WA: CD98 regulates vascular smooth muscle cell proliferation in atherosclerosis. Atherosclerosis 256: 105-114, 2017.

3. Hassan MO: The role of circulating endotoxaemia as a proinflammatory mediator of atherosclerosis in chronic kidney disease patients. BMJ 288: 283-284, 2016

4. Groh L, Keating ST, Joosten LAB, Netea MG and Riksen NP: Monocyte and macrophage immunometabolism in atherosclerosis. Semin Immunopathol 40: 203-214, 2018.

5. Chistiakov DA, Melnichenko AA, Myasoedova VA, Grechko AV and Orekhov AN: Mechanisms of foam cell formation in atherosclerosis. J Mol Med (Berl) 95: 1153-1165, 2017.

6. Lao KH,Zeng L and Xu Q: Endothelial and smooth muscle cell transformation in atherosclerosis. Curr Opin Lipidol 26: 449-456, 2015.

7. Francis GA, Allahverdian S, Cheroudi AC, Abraham T and McManus BM: Response to letter regarding article, "contribution of intimal smooth muscle cells to cholesterol accumulation and macrophage-like cells in human atherosclerosis". Circulation 131: e25, 2015.

8. Huang Y, Ma XY, Yang YB, Ren HT, Sun XH and Wang LR: Identification and characterization of microRNAs and their target genes from Nile tilapia (Oreochromis niloticus). Z Natforsch C J Biosci 71: 215-223, 2016.

9. Xu X, Wang X, Fu B, Meng L and Lang B: Differentially expressed genes and microRNAs in bladder carcinoma cell line 5637 and T24 detected by RNA sequencing. Int J Clin Exp Pathol 8: 12678-12687, 2015.

10. Gao ZG, Chen QJ, Shao M, Qian YZ, Zhang LF, Zhang YB and Xiong QX: Preliminary identification of key miRNAs, signaling pathways, and genes associated with Hirschsprung's disease by analysis of tissue microRNA expression profiles. World J Pediatr 13: 489-495, 2017.

11. Brennan E, Wang B, McClelland A, Mohan M, Marai M, Beuscart O, Derouiche S, Gray S, Pickering R, Tikellis C, et al: Protective effect of let-7 miRNA family in regulating inflammation in diabetes-associated atherosclerosis. Diabetes 66: 2266-2277, 2017.

12. Qun L, Wenda X, Weihong S, Jianyang M, Wei C, Fangzhou L, Zhenyao $\mathrm{X}$ and Pingjin G: miRNA-27b modulates endothelial cell angiogenesis by directly targeting Naa15 in atherogenesis. Atherosclerosis 254: 184-192, 2016.

13. de Ronde MWJ, Kok MGM, Moerland PD, Van den Bossche J, Neele AE, Halliani A, van der Made I, de Winther MPJ, Meijers JCM, Creemers EE, et al: High miR-124-3p expression identifies smoking individuals susceptible to atherosclerosis. Atherosclerosis 263: 377-384, 2017. 
14. Kim J, Inoue K, Ishii J, Vanti WB, Voronov SV, Murchison E, Hannon G and Abeliovich A: A MicroRNA feedback circuit in midbrain dopamine neurons. Science 317: 1220-1224, 2007.

15. Sanchez-Simon FM, Zhang XX, Loh HH, Law P-Y and Rodriguez RE: Morphine regulates dopaminergic neuron differentiation via miR-133b. Mol Pharmacol 78: 935-942, 2010.

16. Yin H, Pasut A, Soleimani VD, Bentzinger CF, Antoun G, Thorn S, Seale P, Fernando P, van Ijcken W, Grosveld F, et al: MicroRNA-133 controls brown adipose determination in skeletal muscle satellite cells by targeting Prdm16. Cell Metab 17: 210-224, 2013

17. Li X, Wan X, Chen H, Yang S, Liu Y, Mo W, Meng D, Du W, Huang Y, Wu H, et al: Identification of miR-133b and RB1CC1 as independent predictors for biochemical recurrence and potentia therapeutic targets for prostate cancer. Clin Cancer Res 20: 2312-2325, 2014

18. Li D, Xia L, Chen M, Lin C, Wu H, Zhang Y, Pan S and Li X: miR-133b, a particular member of myomiRs, coming into playing its unique pathological role in human cancer. Oncotarget 8 : 50193-50208, 2017.

19. de Mena L, Coto E, Cardo LF, Díaz M, Blázquez M, Ribacoba R, Salvador C, Pastor P, Samaranch L, Moris G, et al: Analysis of the Micro-RNA-133 and PITX3 genes in Parkinson's disease. Am J Med Genet B Neuropsychiatr Genet 153B: 1234-1239, 2010.

20. Ferreira LRP, Frade AF, Santos RHB, Teixeira PC, Baron MA, Navarro IC, Benvenuti LA, Fiorelli AI, Bocchi EA, Stolf NA et al: MicroRNAs miR-1, miR-133a, miR-133b, miR-208a and miR-208b are dysregulated in Chronic Chagas disease Cardiomyopathy. Int J Cardiol 175: 409-417, 2014.

21. Masè M, Grasso M, Avogaro L, Nicolussi Giacomaz M, D'Amato E, Tessarolo F, Graffigna A, Denti MA and Ravelli F: Upregulation of miR-133b and miR-328 in patients with atrial dilatation: Implications for stretch-induced atrial fibrillation. Front Physiol 10: 1133, 2019

22. Huang B, Jiang X-C, Zhang T-Y, Hu YL, Tabata Y, Chen Z, Pluchino $S$ and Gao JQ: Peptide modified mesenchymal stem cells as targeting delivery system transfected with miR-133b for the treatment of cerebral ischemia. Int J Pharm 531: 90-100, 2017.

23. Zheng CG, Chen BY, Sun RH, Mou XZ, Han F, Li Q, Huang HJ, Liu JQ and Tu YX: miR-133b Downregulation Reduces Vulnerable Plaque Formation in Mice with AS through Inhibiting Macrophage Immune Responses. Mol Ther Nucleic Acids 16 745-757, 2019

24. Zhen Y, Liu J, Huang Y, Wang Y, Li W and Wu J: miR-133b inhibits cell growth, migration, and invasion by targeting MMP9 in non-small cell lung cancer. Oncol Res 25: 1109-1116, 2017.

25. Guo L, Bai H, Zou D, Hong T, Liu J, Huang J, He P, Zhou Q and $\mathrm{He} \mathrm{J}$ : The role of microRNA-133b and its target gene FSCN1 in gastric cancer. J Exp Clin Cancer Res 33: 99, 2014.

26. Cheng Y, Jia B, Wang Y and Wan S: miR-133b acts as a tumor suppressor and negatively regulates ATP citrate lyase via PPAR $\gamma$ in gastric cancer. Oncol Rep 38: 3220-3226, 2017.

27. Wang X, Bu J, Liu X, Wang W, Mai W, Lv B, Zou J, Mo X, Li X, Wang J, et al: miR-133b suppresses metastasis by targeting HOXA9 in human colorectal cancer. Oncotarget 8: 63935-63948, 2017.

28. Zhou Y, Wu D, Tao J, Qu P, Zhou Z and Hou J: MicroRNA-133 inhibits cell proliferation, migration and invasion by targeting epidermal growth factor receptor and its downstream effector proteins in bladder cancer. Scand J Urol 47: 423-432, 2013.

29. Li Y, Xiao L, Li J, Sun P, Shang L, Zhang J, Zhao Q, Ouyang Y, $\mathrm{Li} \mathrm{L}$ and Gong K: MicroRNA profiling of diabetic atherosclerosis in a rat model. Eur J Med Res 23: 55, 2018.

30. Fung E, Tang SM, Canner JP,Morishige K, Arboleda-VelasquezJF, Cardoso AA, Carlesso N, Aster JC and Aikawa M: Delta-like 4 induces notch signaling in macrophages: Implications for inflammation. Circulation 115: 2948-2956, 2007.

31. Quillard T, Devallière J, Coupel S and Charreau B: Inflammation dysregulates Notch signaling in endothelial cells: Implication of Notch2 and Notch4 to endothelial dysfunction. Biochem Pharmacol 80: 2032-2041, 2010

32. LiuZJ,Tan Y,BeechamGW,SeoDM,TianR,LiY,Vazquez-PadronRI, Pericak-Vance M, Vance JM, Goldschmidt-Clermont PJ, et al: Notch activation induces endothelial cell senescence and pro-inflammatory response: Implication of Notch signaling in atherosclerosis. Atherosclerosis 225: 296-303, 2012.

33. Liu Z, Tan Y, Tian R, Li Y, Beecham GW, Seo DM, Vazquez-Padron RI, Pericak-Vance MA, Vance JM, Goldschmidt-Clermont PJ, et al: Notch Signaling Is A Potential Novel Target In Atherosclerosis. J Surg Res 165: 326, 2011.
34. Davis-Knowlton J, Turner JE, Turner A, Damian-Loring S, Hagler N, Henderson T, Emery IF, Bond K, Duarte CW, Vary $\mathrm{CPH}$, et al: Characterization of smooth muscle cells from human atherosclerotic lesions and their responses to Notch signaling. Lab Invest 99: 290-304, 2019.

35. Wang Z, Wang Z, Wang T, Yuan J, Wang X and Zhang Z: Inhibition of miR-34a-5p protected myocardial ischemia reperfusion injury-induced apoptosis and reactive oxygen species accumulation through regulation of Notch Receptor 1 signaling. Rev Cardiovasc Med 20: 187-197, 2019.

36. Lin D, Cui B, Ma J and Ren J: MiR-183-5p protects rat hearts against myocardial ischemia/reperfusion injury through targeting VDAC1. Biofactors 46: 83-93, 2019.

37. Ou M, Zhang C, Chen J, Zhao S, Cui S and Tu J: Overexpression of microRNA-340-5p inhibits pulmonary arterial hypertension induced by acute pulmonary embolism by down-regulating the expression of inflammatory factors interleukin- $1 \beta$ and interleukin-6. Available at SSRN 3365060, 2019.

38. Livak KJ and Schmittgen TD: Analysis of relative gene expression data using real-time quantitative PCR and the $2-\triangle \Delta C T$ method. Methods 25: 402-408, 2001.

39. Kasiewicz LN and Whitehead KA: Silencing TNF $\alpha$ with lipidoid nanoparticles downregulates both TNFa and MCP-1 in an in vitro co-culture model of diabetic foot ulcers. Acta Biomater 32: 120-128, 2016.

40. Talora C, Campese AF, Bellavia D, Felli MP, Vacca A, Gulino A and Screpanti I: Notch signaling and diseases: An evolutionary journey from a simple beginning to complex outcomes. Biochim Biophys Acta 1782: 489-497, 2008.

41. Geng YR, Zhang HL, Dong Y, Liu GY, Xie J and Wang H: Relationship between intercellular adhesion molecule-1 and cerebral infarction. Progress in Modern Biomedicine 22: 4373-4375, 2010 (In Chinese).

42. Xu R, Yin X, Xu W, Jin L, Lu M and Wang Y: Assessment of carotid plaque neovascularization by contrast-enhanced ultrasound and high sensitivity $\mathrm{C}$-reactive protein test in patients with acute cerebral infarction: A comparative study. Neurol Sci 37: 1107-1112, 2016

43. Wang Y,Liu T, Huang P,Zhao H,Zhang R, Ma B, Chen K, Huang F, Zhou X, Cui C, et al: A novel Golgi protein (GOLPH2)-regulated oncolytic adenovirus exhibits potent antitumor efficacy in hepatocellular carcinoma. Oncotarget 6: 13564-13578, 2015.

44. Yang L, Hou J, Cui XH, Suo LN and Lv YW: MiR-133b regulates the expression of CTGF in epithelial-mesenchymal transition of ovarian cancer. Eur Rev Med Pharmacol Sci 21: 5602-5609, 2017

45. Trajkovski M, Ahmed K, Esau CC and Stoffel M: MyomiR-133 regulates brown fat differentiation through Prdm16. Nat Cell Biol 14: 1330-1335, 2012.

46. Dumitriu IE and Kaski JC: The role of lymphocytes in the pathogenesis of atherosclerosis: Focus on CD4+ T cell subsets. In: Inflammatory Response in Cardiovascular Surgery. Gabriel EA and Gabriel SA (eds). Springer, London, pp9-14, 2013.

47. Qin M, Luo Y, Meng XB, Wang M, Wang HW, Song SY, Ye JX, Pan RL, Yao F, Wu P, et al: Myricitrin attenuates endothelial cell apoptosis to prevent atherosclerosis: An insight into PI3K/Akt activation and STAT3 signaling pathways. Vascul Pharmacol 70: 23-34, 2015

48. Chhour P, Naha PC, O'Neill SM, Litt HI, Reilly MP, Ferrari VA and Cormode DP: Labeling monocytes with gold nanoparticles to track their recruitment in atherosclerosis with computed tomography. Biomaterials 87: 93-103, 2016.

49. Fuhrman B, Koren L, Volkova N, Keidar S, Hayek T and Aviram M: Atorvastatin therapy in hypercholesterolemic patients suppresses cellular uptake of oxidized-LDL by differentiating monocytes. Atherosclerosis 164: 179-185, 2002.

50. He B, Zhou L, Shen LH, Ha LH, Pu J, Shao Q, Wang L and Zeng JZ: RXR agonists inhibit PMA-induced differentiation of monocytic THP-1 cells into macrophages. Circulation 118: S277, 2008.

51. Wang YS, Hsi E, Cheng HY, Hsu SH, Liao YC and Juo SH: Let-7g suppresses both canonical and non-canonical NF- $x$ B pathways in macrophages leading to anti-atherosclerosis. Oncotarget 8: 101026-101041, 2017.

52. Ping S, Li Y, Liu S, Zhang Z, Wang J, Zhou Y, Liu K, Huang J, Chen D, Wang J, et al: Simultaneous increases in proliferation and apoptosis of vascular smooth muscle cells accelerate diabetic mouse venous atherosclerosis. PLoS One 10: e0141375, 2015.

53. Lee GL, Wu JY, Tsai CS, Lin CY, Tsai YT, Lin CS, Wang YF, Yet SF, Hsu YJ and Kuo CC: TLR4-activated MAPK-IL-6 axis regulates vascular smooth muscle cell function. Int J Mol Sci 17: $17,2016$. 
54. Liang Y, Gao H, Wang J, Wang Q, Zhao S, Zhang J and Qiu J: Alleviative effect of grape seed proanthocyanidin extract on small artery vascular remodeling in spontaneous hypertensive rats via inhibition of collagen hyperplasia. Mol Med Rep 15: 2643-2652, 2017.

55. Yang L, Yaling H, Chenghui $Y$ and Xiaoxiang T: ASSA14-03-19 The change of cellular repressor of E1A-stimulated genes during vascular remodelling in a mouse model of arterial injury. Heart 101 (Suppl 1): A14-A15, 2015.

56. Heijnen BF, Pelkmans LP, Danser AH, Garrelds IM, Mullins JJ, De Mey JG, Struijker-Boudier HA and Janssen BJ: Cardiac remodeling during and after renin-angiotensin system stimulation in Cypla1-Ren2 transgenic rats. J Renin Angiotensin Aldosterone Syst 15: 69-81, 2014.

57. Bodle JD, Feldmann E, Swartz RH, Rumboldt Z, Brown T and Turan TN: High-resolution magnetic resonance imaging: An emerging tool for evaluating intracranial arterial disease. Stroke 44: 287-292, 2013.

58. Lim TT, Liang DH, Botas J, Schroeder JS, Oesterle SN and Yeung AC: Role of compensatory enlargement and shrinkage in transplant coronary artery disease. Serial intravascular ultrasound study. Circulation 95: 855-859, 1997.

59. Hecht HS, Achenbach S, Kondo T and Narula J: High-Risk Plaque Features on Coronary CT Angiography. JACC Cardiovasc Imaging 8: 1336-1339, 2015.

60. Madrigal-Matute J, López-Franco O, Blanco-Colio LM, Muñoz-García B, Ramos-Mozo P, Ortega L, Egido J and Martín-Ventura JL: Heat shock protein 90 inhibitors attenuate inflammatory responses in atherosclerosis. Cardiovasc Res 86: 330-337, 2010.

61. Yang M, Deng C, Wu D, Zhong Z, Lv X, Huang Z, Lian N, Liu K and Zhang Q: The role of mononuclear cell tissue factor and inflammatory cytokines in patients with chronic thromboembolic pulmonary hypertension. J Thromb Thrombolysis 42: 38-45, 2016.

62. Torisu H, Ono M, Kiryu H, Furue M, Ohmoto Y, Nakayama J, Nishioka Y, Sone S and Kuwano M: Macrophage infiltration correlates with tumor stage and angiogenesis in human malignant melanoma: Possible involvement of TNFalpha and IL-1 $\alpha$. Int $\mathbf{J}$ Cancer 85: 182-188, 2000.
63. Tay C, Liu YH, Hosseini H, Kanellakis P, Cao A, Peter K, Tipping P, Bobik A, Toh BH and Kyaw T: B cell-specific depletion of TNF $\alpha$ inhibits atherosclerosis development and plaque vulnerability to rupture by reducing cell death and inflammation. Cardiovasc Res 111: 385-397, 2016.

64. Voloshyna I, Seshadri S, Anwar K, Littlefield MJ, Belilos E, Carsons SE and Reiss AB: Infliximab reverses suppression of cholesterol efflux proteins by TNF- $\alpha$ : A possible mechanism for modulation of atherogenesis. BioMed Res Int 2014: 312647 2014.

65. Gandhirajan RK, Staib PA, Minke K, Gehrke I, Plickert G, Schlösser A, Schmitt EK, Hallek M and Kreuzer KA: Small molecule inhibitors of $\mathrm{Wnt} / \beta$-catenin/lef- 1 signaling induces apoptosis in chronic lymphocytic leukemia cells in vitro and in vivo. Neoplasia 12: 326-335, 2010.

66. Zhang Z, Ma N, Zheng Y and Zhang L: Association of serum immunoglobulin-G to Porphyromonas gingivalis with acute cerebral infarction in the Chinese population. J Indian Soc Periodontol 19: 628-632, 2015.

67. He X, Li DR, Cui C and Wen LJ: Clinical significance of serum MCP-1 and VE-cadherin levels in patients with acute cerebral infarction. Eur Rev Med Pharmacol Sci 21: 804-808, 2017.

68. Baeten JT and Lilly B: Differential Regulation of NOTCH2 and NOTCH3 Contribute to Their Unique Functions in Vascular Smooth Muscle Cells. J Biol Chem 290: 16226-16237, 2015.

69. Baeten JT and Lilly B: Notch Signaling in Vascular Smooth Muscle Cells. Adv Pharmacol 78: 351-382, 2017.

70. Sweeney C, Morrow D, Birney YA, Coyle S, Hennessy C, Scheller A, Cummins PM, Walls D, Redmond EM and Cahill PA: Notch 1 and 3 receptor signaling modulates vascular smooth muscle cell growth, apoptosis, and migration via a CBF-1/RBP-Jk dependent pathway. FASEB J 18: 1421-1423, 2004.

71. Zhao-Jun L, Yurong T, Beecham GW, et al: Notch activation induces endothelial cell senescence and pro-inflammatory response: Implication of Notch signaling in atherosclerosis. J Vasc Surg 53: 81S-82S, 2015. 